MAKSIMUM: Media Akuntansi Universitas Muhammadiyah Semarang, Vol.10 (1) 2020, 12-22

https://jurnal.unimus.ac.id/index.php/MAX

Registered with the Indonesian Institute of Sciences with p-ISSN: 20872836 and e-ISSN: 2580-9482

\title{
Analisis Faktor-Faktor yang Mempengaruhi Net Interest Margin Pada Perusahaan Perbankan yang Terdaftar Di Bursa Efek Indonesia Periode 2012-2016
}

\author{
Deny Asna Widyanto1, R. Ery Wibowo Agung ${ }^{2}$, Alwiyah ${ }^{3}$ \\ ${ }^{123}$ Fakultas Ekonomi, Unversitas Muhammadiyah Semarang, Indonesia
}

\begin{abstract}
Info Article
History Article:

Submitted: 13 Januari

2020

Revised:23Januari 2020

Accepted: 5 Februari

2020

\section{Keywords:}

liquidity, capital,

efficiency, bank size, Non

Performing Loans and

Net Interest Margin

Abstract

This study aims to examine the effect of liquidity, capital, efficiency, bank size and Non Performing Loans (NPL) on Net Interest Margin (NIM). The population in this study were all banking companies (commercial banks) listed (Go Public) on the Indonesia Stock Exchange (BEI) for the period 2012-2016, totaling 33 banks. The method of taking by judgment sampling method, which is one form of purposive sampling. The data used are secondary data with data analysis using linear regression analysis. Based on the research results, it was found that LDR had a positive and significant effect on NIM. EA has no significant effect on NIM. BOPO has no significant effect on NIM. Bank size has no significant effect on NIM. NPL has a significant effect on NIM. Liquidity, Efficiency Capital, Company Size and Non-Performing Loans have a significant effect on Net Interest Margin (NIM) together.
\end{abstract}

JEL classifications:

G31, G34

How to Cite: Widyanto, A.,D., Agung, R.,E.,W., dan Alwiyah. (2020). Analisis Faktor-Faktor yang Mempengaruhi Net Interest Margin Pada Perusahaan Perbankan yang Terdaftar Di Bursa Efek Indonesia Periode 2012-2016. MAKSIMUM, Vol.1O(1), 12-22

\begin{tabular}{ll}
\hline${ }^{\circ}$ correspondence Address: Jl. Kedungmundu No.18, Kedungmundu, Kec. Tembalang, Kota & $2086-0668$ (P-ISSN) \\
Semarang, Jawa Tengah 50273 & $2337-5434$ (e-ISSN)
\end{tabular}

Institutional address: Universitas Muhammadiyah Semarang

E-mail: deny@gmail.com 


\section{PENDAHULUAN}

Bank mempunyai fungsi sebagai penyalur dana dari masyarakat kepada pihak yang membutuhkan dana (intermediasi) dengan biaya seminimal mungkin dalam rangka meningkatkan kesejahteraan sosial. Biaya intermediasi keuangan dapat diukur dengan selisih antara pendapatan bunga yang diperoleh bank dengan beban bunga yang harus ditanggung oleh bank (net interest margin) (Tin et al. 2011). Semakin rendah Net Interest Margin (NIM), maka akan semakin rendah biaya intermediasi keuangan. NIM juga merupakan salah satu indikator profitabilitas bank (khususnya dalam usaha yang menghasilkan pendapatan bunga) sehingga NIM yang tinggi dapat menunjukkan profitabilitas yang tinggi (Iswi dan Toruan, 2010). NIM dapat dipengaruhi oleh beberapa faktor diantaranya likuiditas, modal, efisiensi, ukuran bank dan Non Performing Loan (NPL) (Mardiyati, dkk, 2012).

NIM pada perusahaan perbankan nasional dari tahun 2015 - 2016 mengalami penurunan sebanyak $0.02 \%$. Hal ini menunjukan tingkat keutungan belum tercapai secara maksimal. Likuiditas (LDR) pada perusahaan perbankan nasional dari tahun 2015 - 2016 mengalami penurunan sebanyak 1,92 \%.Hal ini menunjukan bahwa total kredit yang diberikan kepada pihak ketiga mengalami penurunan. Modal (EA) pada perusahaan perbankan nasional dari tahun 2015 - 2016 mengalami kenaikan sebanyak 1,66 \%, hal ini menunjukan bahwa bank mempunyai modal yang cukup dan memungkinkan bank untuk meningkatkan penyaluran kredit dan atau mengurangi kewajiban membayar hutang. Efisiensi (BOPO) pada perusahaan perbankan nasional mengalami penurunan di tahun 2015-2016 sebanyak 3,4 \%, hal ini menunjukan bahwa biaya operasional yang merendah atau pendapatan operasional mengalami penurunan. Ukuran Bank (Size) pada perusahaan perbankan nasional dari tahun 2015 - 2016 mengalami kenaikan sebanyak $0,05 \%$, hal ini menunjukan bahwa bank besar dapat memperoleh deposit dan transaksi penyaluran kredit yang lebih besar dan dalam prosesnya memiliki kekuatan untuk mendapat selisih bunga yang lebih besar. Non Performing Loan (NPL) pada perusahaan perbankan nasional dari tahun 2015 - 2016 mengalami kenaikan 1,08\%, hal ini menunjukan bahwa tingkat kredit bermasalah / macet mengalami peningkatan.

Penelitian mengenai pengaruh likuiditas, modal, efisiensi, ukuran bank dan Non Performing Loan (NPL) terhadap Net Interest Margin (NIM) akan dilakukan pada perusahaan perbankan yang terdaftar di BEI periode 2012 - 2016. Penelitian yang akan dilakukan merupakan replikasi dari penelitian yang dilakukan oleh Marozva (2015) serta Sarwendah Nugrahaning, Sugeng Wahyudi (2016). Penelitian ini mengembangkan saransaran dari penelitian terdahulu yang pada intinya untuk menambahkan variabel independen yang lain yang mempengaruhi Net Interest Margin (NIM).

Perbedaan penelitian dari Marozva (2015) dengan penelitian yang akan dilakukan adalah pada penambahan variabel penelitian, periode penelitian dan obyek penelitian yang berbeda. Pada penelitian Marozva (2015) variabel yang digunakan hanya likuiditas dan resiko kredit sedangkan penelitian yang akan dilakukan variabel meliputi likuiditas, modal, efisiensi, ukuran bank dan resiko kredit. Untuk periode yang digunakan pada penelitian Marozva (2015) tahun 1998 sampai dengan tahun 2014 sedangkan penelitian ini periode yang digunakan tahun 2012 - 2016. Untuk obyek penelitian penelitian Marozva (2015) menggunakan obyek penelitian bank di Afrika sedangkan penelitian ini menggunakan obyek penelitian bank di Indonesia.

Penelitian ini menggunakan agency theory dan signaling theory. Brigham dan Houston (2011) signal adalah suatu tindakan yang diambil perusahaan untuk memberi petunjuk bagi investor tentang bagaimana manajemen memandang prospek perusahaan. Signalling theory menjelaskan mengapa perusahaan mempunyai dorongan untuk memberikan informasi laporan keuangan pada pihak eksternal. Dorongan perusahaan untuk memberikan informasi karena terdapat asimetri informasi antara perusahaan dan pihak luar karena perusahaan mengetahui lebih banyak mengenai perusahaan dan prospek yang akan datang daripada pihak luar (investor dan kreditur). 
Net Interest Margin (NIM) merupakan Bunga bank dapat diartikan sebagai balas jasa yang diberikan oleh bank yang berdasarkan prinsip konvensional kepada nasabah yang membeli atau menjual produknya, diperoleh selisih bunga simpanan yang diberikan kepada penyimpan dengan bunga pinjaman atau kredit yang disalurkan yang dikenal dengan istilah spread based (Kasmir: 2013). Likuiditas merupakan ukuran kemampuan bank untuk membayar kembali seluruh kewajiban lancarnya. Bank dituntut selalu dalam posisi siap membayar, artinya bank harus mempunyai cadangan uang (idle fund) yang cukup. Di sisi lain, usaha bank yang utama adalah memutar uang nasabahnya untuk mendapatkan keuntungan. Kosmidou et al. (2008) mengukur kecukupan modal digunakan rasio equity to assets (EA).

BOPO adalah gambaran pengeluaran dari manajemen bank, dan pengeluaran diperkirakan berhubungan dengan profitabilitas.Efisiensi biaya operasional terhadap pendapatan operasional (BOPO) digunakan sebagai indikator kemampuan manajemen dalam mengontrol biaya (Kosmidou et al., 2008). Ukuran bank menggambarkan besar kecilnya suatu perusahaan perbankan. Menurut Kosmidou et al. (2008), bank besar akan menghasilkan skala ekonomi dengan biaya yang lebih rendah, atau lingkup ekonomi yang menghasilkan diversifikasi kredit dan produk. Non Performing Loan, Salah satu risiko yang dihadapi bank adalah risiko tidak terbayarnya kredit yang telah diberikan atau disebut risiko kredit.

\section{Kerangla konseptual penelitian}

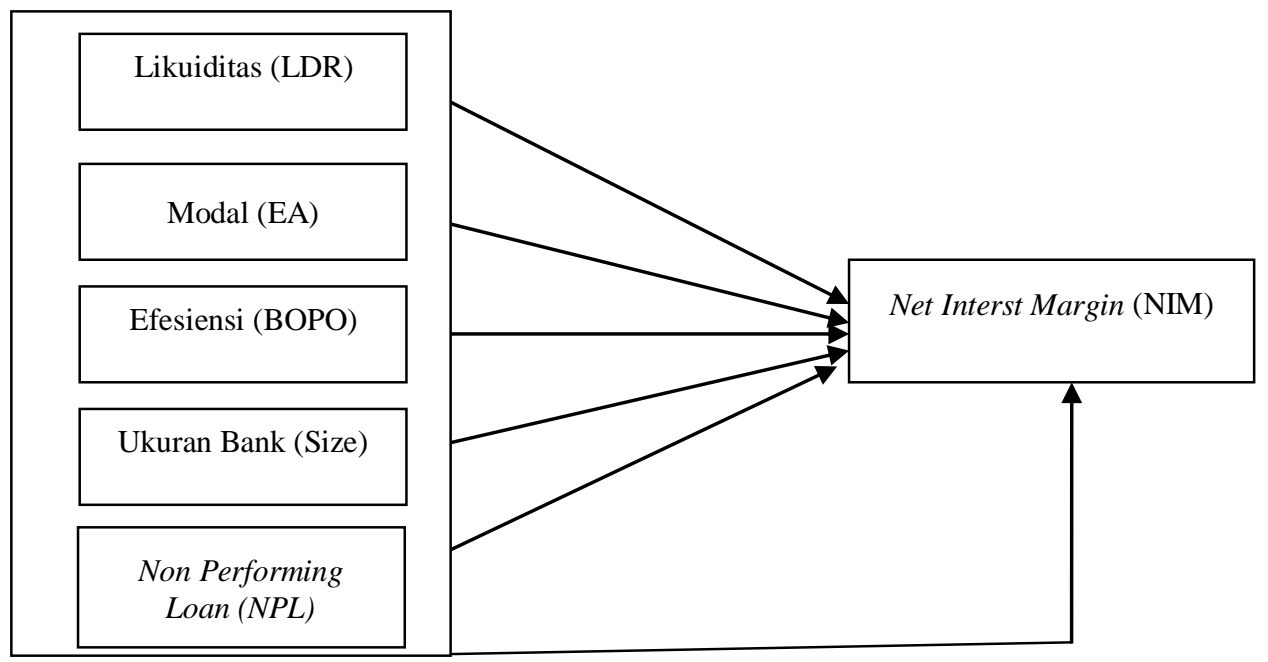

Gambar 1. Kerangka konseptual penelitian

\section{Hipotesis penelitian}

H1 :Likuiditas (LDR) mempunyai pengaruh positif dan signifikan terhadap Net Interest Margin (NIM)

H2 :Modal (EA) mempunyai pengaruh positif dan signifikan terhadap Net Interest Margin (NIM)

H3 :Efisiensi (BOPO) mempunyai pengaruh negatif dan signifikan terhadap Net Interest Margin (NIM)

H4 :Ukuran bank(size) mempunyai pengaruh positif dan signifikan terhadap Net Interest Margin (NIM)

H5 :Non Performing Loan (NPL) mempunyai pengaruh negatif dan signifikan terhadap NetInterest Margin (NIM)

\section{METODE}

Populasi penelitian ini adalah seluruh perusahaan perbankan konvensional yang listing di Bursa Efek Indonesia (BEI) periode 2012-2016. Sampel dalam penelitian ini 
adalah perusahaan perbankan yang tercatat (Go Public) di Bursa Efek Indonesia (BEI) periode 2012 - 2016. Metode pengambilan sampel yang digunakan adalah metode judgment sampling, yaitu salah satu bentuk purposive sampling dengan mengambil sampel yang telah ditentukan sebelumnya berdasarkan maksud dan tujuan penelitian.

\section{Pengukuran Variabel \\ Net Interest Margin}

Menurut Janrosl \& Yuliani (2017) Net Interest Margin merupakan perbandingan antara pendapatan bunga bersih terhadap aktiva produktifnya. Net Interest Margin (NIM) dapat dihitung sebagai berikut (Janrosl \& Yuliani, 2017):

$$
\mathrm{NIM}=\frac{\text { Pendapatan Bungan Bersih }}{\text { Aktiva Produktif }} \quad 100 \%
$$

\section{Likuiditas (LDR)}

Rasio LDR merupakan perbandingan antara total kredit yang diberikan bank terhadap total dana pihak ketiga yang diterima bank. Berdasarkan SE BI No. 15/15/PBI/2013, LDR adalah rasio kredit yang diberikan kepada pihak ketiga dalam rupiah dan valuta asing. terhadap: dana pihak ketiga yang tidak termasuk dana antar bank. Likuiditas dihitung dengan menggunakan LDR:

$$
\mathrm{LDR}=\frac{\text { Total Kredit yang diberikan }}{\text { Total dana pihak ketiga }} \quad 100 \%
$$

\section{Modal (EA)}

Rasio ini mengukur persentase modal ekuitas yang terdapat dalam total aset. Menurut Kosmidou et al. (2008), rasio modal atau Equity to Assets (EA) dapat dihitung sebagai berikut:

$$
\mathrm{EA}=\frac{\text { Ekuitas }}{\text { Total Asset }} \quad 100 \%
$$

\section{Efisiensi (BOPO)}

Rasio yang sering disebut rasio efisiensi ini digunakan untuk mengukur kemampuan manajemen bank dalam mengendalikan biaya operasional terhadap pendapatan operasional. Menurut Kosmidou et al. (2008), rasio efisiensi atau Biaya operasional terhadap pendapatan operasional (BOPO) dapat dihitung sebagai berikut:

$$
\text { BOPO }=\frac{\text { Beban Operasional }}{\text { Pendapatan Operasional }} \quad 100 \%
$$

\section{Ukuran Bank (Size)}

Ukuran bank menggambarkan besar kecilnya suatu perusahaan perbankan. Ukuran bank diukur dengan menggunakan Ln (Total Asset) karena nilai Total asset diangap mampu menggambarkan ukuran suatu perusahaan (Kosmidou et al., 2008). 


\section{Non Performing Loan (NPL)}

Menurut Sabir (2012) Non Performing Loan (NPL) menunjukan bagaimana bank mengelola penyaluran kreditnya jugadapat menggambarkan tingkat kredit bermasalah yang dimiliki suatu bank. NPL yang tinggi menyebabkan penurunan tingkat kesehatan bank. Rasio Non Performing Loan dirumuskan sebagai berikut (Christiano, dkk., 2014):

$$
\mathrm{NPL}=\frac{\text { Kredit bermasalah }}{\text { Total kredit }} \quad 100 \%
$$

\section{Metode Analisis dan Pengujian Hipotesis}

Statistik deskriptif dalam penelitian pada dasarnya merupakan proses transformasi data penelitian dalam bentuk tabulasi sehingga mudah dipahami dan diinterpretasikan. Uji normalitas bertujuan untuk menguji apakah dalam model regresi, variabel terikat dan veriabel bebas keduanya mempunyai distribusi normal ataukah tidak. Uji Autokorelasi bertujuan untuk mengetahui dalam model regresi linier terdapat antara pengganggu pada periode $t$ dengan kesalahan pada periode $t-1$ (sebelumnya) (Ghozali, 2013). Uji heteroskedastisitas adalah suatu keadaan dimana varians dan kesalahan pengganggu tidak konstan untuk semua variabel bebas. Uji Multikolinearitas berarti ada hubungan linier yang sempurna atau pasti diantara beberapa atau semua variabel yang independen dari model yang ada. Uji Koefisien Determinasi (Goodness of fit) bertujuan untuk mengukur berapa persen variabel independen berpengaruh terhadap variabel dependen. Nilai $\mathrm{R}^{2}$ menunjukkan seberapa besar proporsi dari total variasi variabel tidak bebas yang dapat dijelaskan oleh variabel penjelasnya. Uji $\mathrm{F}$ ini untuk mengidentifikasi pengaruh variabel independen terhadap variabel dependen dengan menggunakan SPSS (Ghozali, 2013). Uji statistik t menunjukkan seberapa jauh pengaruh satu variabel independen atau variabel penjelas secara individual dalam menerangkan variabel dependen (Ghozali, 2013).

\section{HASIL DAN PEMBAHASAN}

\section{Statistik Deskriptif Variabel}

Sampel yang digunakan untuk menguji pengaruh LDR, EA, BOPO, Ukuran bank dan NPL terhadap NIM pada perusahaan perbankan untuk periode pengamatan tahun 20122016. Gambaran umum sampel data penelitian dapat dilihat pada deskripsi statistik penelitian pada tabel 4.2 sebagai berikut:

Tabel 1.Descriptive Statistics

\begin{tabular}{cccccc}
\hline & N & Min & Max & Mean & Std. Dev \\
\hline LDR & 125 & 47,7 & 193,9 & 82,431 & 14,4824 \\
EA & & 7,02 & 23,76 & 12,989 & 3,56486 \\
BOPO & & 14,4 & 87,84 & 49,063 & 13,7357 \\
UKURAN & & 14,7 & 20,76 & 17,711 & 1,62906 \\
NPL & &, 31 & 20,33 & 3,3344 & 3,30208 \\
NIM & & 1,53 & 16,39 & 8,7365 & 2,09322 \\
\hline
\end{tabular}

Sumber : Data sekunder yang diolah, 2018

\section{Uji Normalitas}

Uji Normalitas adalah sebuah uji untuk mengetahui apakah model regresi variabel dependen dan variabel independen atau keduanya mempunyai distribusi normal atau tidak. Uji normalitas menggunakan test statistik berdasarkan nilai Kolmogorov- 
Smirnov Test. Hasil uji normalitas menggunakan test statistik Kolmogorov-Smirnov Testsebagai berikut :

Tabel 2. Hasil Pengujian Normalitas

\begin{tabular}{ccr}
\hline & & Unstandardized Residual \\
\hline \multirow{2}{*}{ Normal Parameters ${ }^{\mathrm{a}, \mathrm{b}}$} & Mean & 125 \\
& Std. Deviation &, 0000000 \\
Most Extreme & Absolute &, 13018621 \\
Differences & Positive &, 076 \\
& Negative &, 076 \\
Test Statistic &,- 060 \\
Asymp. Sig. (2-tailed) &, 076 \\
\end{tabular}

\section{Uji Asumsi Klasik}

Autokorelasi

Uji autokorelasi adalah model untuk menguji apakah kesalahan observasi berkorelasi satu sama lain. Cara pengujiannya menggunakan Statistik $d$ Durbin-Watson (The Durbin-Watson d Statistic). Hasil uji autokorelasi pengaruh LDR, EA, BOPO, Ukuranbank dan NPL terhadap NIM sebagai berikut:

Tabel 3. Durbin-Watson

\begin{tabular}{cccccc} 
Model & $\mathbf{R}$ & \multicolumn{2}{l}{$\mathbf{R}$ Square Adjusted R Square Std. Error of the Estimate Durbin-Watson } \\
\hline 1 &, $627^{\mathrm{a}}$ &, 393 &, 367 &, 13289307 & 2,164
\end{tabular}

sumber : Data sekunder yang diolah, 2018

\section{Uji Heteroskedastisitas}

Uji heteroskedastisitas adalah suatu keadaan dimana varians dan kesalahan pengganggu tidak konstan untuk semua variabel bebas. Model regresi yang baik adalah tidak terjadi heteroskedastisitas. Hasil uji heteroskedastisitas pengaruh LDR, EA, BOPO, ukuran bank dan NPL terhadap NIM dengan uji Glejser sebagai berikut :

Tabel 4. Hasil UjiHeteroskedastisitas

\begin{tabular}{|c|c|c|c|c|c|c|}
\hline & \multirow[t]{2}{*}{ Model } & \multicolumn{2}{|c|}{ Unstandardized Coefficients } & \multirow{2}{*}{$\begin{array}{c}\text { Standardized } \\
\text { Coefficients }\end{array}$} & \multirow[t]{2}{*}{$\mathbf{t}$} & \multirow[t]{2}{*}{ Sig. } \\
\hline & & B & Std. Error & & & \\
\hline \multirow[t]{6}{*}{1} & (Constant) & ,009 & ,039 & & ,223 & ,824 \\
\hline & LDR & ,062 & ,000 &, 040 & ,399 & 691 \\
\hline & $\mathrm{EA}$ & ,095 & ,001 & ,015 & 136 & ,892 \\
\hline & BOPO & ,001 & ,000 & ,089 &, 722 &, 472 \\
\hline & UKURAN & ,001 & ,002 &,- 014 &,- 123 & ,903 \\
\hline & NPL &, 001 & ,001 & ,087 & ,855 & ,394 \\
\hline
\end{tabular}

Sumber : Data sekunder yang diolah, 2018 


\section{Uji Multikolinieritas}

Pengujian ini untuk mengetahui adanya hubungan antar variabel independen yang "sempurna" atau pasti di antara beberapa atau semua variabel independen yang menjelaskan model regresi. Model regresi yang baik seharusnya tidak terjadi korelasi di antara variabel independen.

Tabel 5 Uji Multikolinieritas

\begin{tabular}{|c|c|c|c|}
\hline & \multirow{2}{*}{ Model } & \multicolumn{2}{|c|}{ Collinearity Statistics } \\
\hline & & Tolerance & VIF \\
\hline \multirow[t]{6}{*}{1} & (Constant) & & \\
\hline & LDR &, 808 & 1,237 \\
\hline & $\mathrm{EA}$ & ,669 & 1,495 \\
\hline & BOPO &, 541 & 1,850 \\
\hline & UKURAN & ,594 & 1,683 \\
\hline & NPL & ,794 & 1,260 \\
\hline
\end{tabular}

Sumber : data diolah, 2018

\section{Pengujian Hipotesis}

\section{Analisis Regresi Berganda}

Analisis regresi berganda digunakan untuk mengetehui pengaruh variabel independen terhadap dependen dengan skala pengukuran dalam suatu persamaan linier. Hasil persamaan regresi pengaruh LDR, EA, BOPO, Ukuranbank dan NPL terhadap NIM pada perusahaan perbankan untuk periode pengamatan tahun 2012 -2016 sebagai berikut :

Tabel 6. Hasil Pengujian Regresi

\begin{tabular}{|c|c|c|c|c|c|c|}
\hline & \multirow{2}{*}{ Model } & \multicolumn{2}{|c|}{$\begin{array}{l}\text { Unstandardized } \\
\text { Coefficients }\end{array}$} & \multirow{2}{*}{$\begin{array}{c}\begin{array}{c}\text { Standardized } \\
\text { Coefficients }\end{array} \\
\text { Beta }\end{array}$} & \multirow[t]{2}{*}{$\mathbf{t}$} & \multirow{2}{*}{ Sig. } \\
\hline & & B & Std. Error & & & \\
\hline \multirow[t]{6}{*}{1} & (Constant) & ,215 & ,228 & &, 942 & ,348 \\
\hline & LDR & ,005 & ,001 & ,406 & 5,111 & ,000 \\
\hline & EA & ,002 & ,004 & ,034 & ,393 &, 695 \\
\hline & $\mathrm{BOPO}$ &,- 001 & 001 &,- 047 &,- 483 &, 630 \\
\hline & UKURAN &,- 014 & ,010 &,- 141 & $-1,518$ &, 132 \\
\hline & NPL &, 026 & ,004 &, 523 & 6,525 &, 000 \\
\hline
\end{tabular}

Sumber : Data diolah, 2018

$$
\mathbf{Y}=0,215+0,005 \times 1+0,002 X 2-0,001 \times 3-0,014 \times 4+0,026 \times 5+e
$$

Hasil persamaan regresi berganda tersebut di atas memberikan pengertian sebagai berikut :

1. Nilai konstanta sebesar 0,215 menunjukkan nilai positif. Berarti apabila LDR, EA, BOPO, Ukuran bank dan NPL nilainya 0, maka NIM nilainya 0,215.

2. Nilai koefisien regresi LDR $\left(b_{1}\right)$ sebesar 0,005 dan bertanda positif $(+)$ hal ini menunjukkan bahwa apabila LDR mengalami kenaikan satu satuan, maka NIM akan meningkat sebesar 0,005 satuan..

3. Nilai koefisien regresi EA $\left(b_{2}\right)$ sebesar 0,002dan bertanda positif $(+)$ hal ini menunjukkan bahwa apabila EAmengalami kenaikan satu satuan, maka NIM akan mengalami peningkatan sebesar 0,002 . 
4. Nilai koefisien regresi BOPO $\left(b_{3}\right)$ sebesar - 0,001dan bertanda negatif $(-)$ hal ini menunjukkan bahwa apabila BOPOmengalami peningkatan satu satuan, maka NIM akanmengalami penurunan sebesar 0,001.

5. Nilai koefisien regresi Ukuran bank $\left(\mathrm{b}_{4}\right)$ sebesar - 0,014dan bertanda negatif (-) hal ini menunjukkan bahwa apabila Ukuran bankmengalami peningkatan sebanyak satu satuan, maka NIM akan mengalami penurunan sebanyak 0,014.

6. Nilai koefisien regresi NPL (b) sebesar 0,026dan bertanda positif $(+)$ hal ini menunjukkan bahwa apabila NPLmengalami kenaikan sebanyak satu satuan, maka NIM akan mengalami peningkatan sebanyak 0,026.

\section{Uji Koefisien Determinasi}

Koefisien determinasi $\left(\mathrm{R}^{2}\right)$ dimana dalam penelitian ini menggunakan AdjustedR Square mengukur seberapa jauh kemampuan variabel independen dalam menjelaskan variasi variabel dependen. Hasil koefisien determinasi pengaruh LDR, EA BOPO, Ukuran bank dan NPL terhadap NIM pada perusahaan perbankan untuk periode pengamatan tahun $2012-2016$ dapat dilihat pada tabel di bawah ini :

Tabel 7. Uji Koef Determinasi

\begin{tabular}{ccccc}
\hline Model & $\mathbf{R}$ & R Square & $\begin{array}{c}\text { Adjusted } \mathbf{R} \\
\text { Square }\end{array}$ & $\begin{array}{c}\text { Std. Error of the } \\
\text { Estimate }\end{array}$ \\
\hline 1 &, $627^{\mathrm{a}}$ &, 393 &, 367 &, 13289307 \\
\hline
\end{tabular}

Sumber : Data diolah, 2018

Berdasarkan tabel 4.8 di atas hasil uji regresi didapatkan angka koefisien adjusted $R$ Square sebesar 0,367. Hal ini berarti bahwa sebesar 36,7\% NIM dapat dijelaskan oleh LDR, EA, BOPO, Ukuran bank dan NPL. Sedangkan sisanya $100 \%-36,7 \%=63,3 \%$ dijelaskan oleh variabel lain di luar model.

\section{Uji F (Uji Kesesuaian Model / Good of Fit)}

Uji F digunakan untuk menunjukkan pengaruh secara bersama-sama / simultan variabel independen terhadap variabel dependen serta untuk mengetahui kelayakan model persamaan regresi.

Tabel 8. Uji F

\begin{tabular}{|c|c|c|c|c|c|c|}
\hline & Model & Sum of Squares & df & Mean Square & $\mathbf{F}$ & Sig. \\
\hline \multirow[t]{3}{*}{1} & Regression & 1,361 & 5 & ,272 & 15,409 &, $000^{b}$ \\
\hline & Residual & 2,102 & 119 & ,018 & & \\
\hline & Total & 3,462 & 124 & & & \\
\hline
\end{tabular}

Sumber : Data sekunder yang diolah, 2018

Berdasarkan tabel 4.9 di atas dapat diketahui hasil $\mathrm{F}$ hitung 15,409 dan tingkat probabilitas $0,000<0,05$, sehingga hipotesis keenam $\left(\mathrm{H}_{6}\right)$ : Likuiditas, Modal Efisiensi, Ukuran Perusahaan dan Non Performing Loan mempunyai pengaruh signifikan terhadap Net Interest Margin (NIM) dapat diterima. Disamping itu persamaan regresi memenuhi persyaratan goodness of fit dan model regresi tersebut layak untuk diujikan ke pengujian selanjutnya. 


\section{Uji Hipotesis}

Uji hipotesis dalam penelitian ini menggunakan uji t,dimana untuk menunjukkan seberapa jauh pengaruh satu variabel independen atau variabel penjelas secara individual dalam menerangkan variabel dependen.

Tabel 9. Uji t

\begin{tabular}{ccccc}
\hline No & Ket & B & Sig. & Hipotesis \\
\hline 1 & H1 & 0,005 & 0,000 & Diterima \\
2 & H2 & 0,002 & 0,695 & Ditolak \\
3 & H3 & $-0,001$ & 0,630 & Ditolak \\
4 & H4 & $-0,014$ & 0,132 & Ditolak \\
5 & H5 & 0,026 & 0,000 & Ditolak \\
\hline
\end{tabular}

Sumber : Data diolah, 2018

\section{KESIMPULAN DAN SARAN}

Berdasarkan analisis data yang dilakukan pada bab sebelumnya mengenai pengaruh Likuiditas (LDR), Modal Efisiensi (EA), Ukuran Perusahaan (Size) dan Non Performing Loan(NPL) terhadap Net Interest Margin (NIM) pada perusahaan Perbankan yang terdaftar di BEI periode 2012-2016 dapat disimpulkan sebagai berikut :

1. Hasil pengujian analisis regresi diperoleh koefisien regresi LDR sebesar 0,005 dan tingkat signifikan sebesar $0,000<0,05$, maka variabel LDR berpengaruh positif dan signifikan terhadap NIM, berarti hipotesis pertama $(\mathrm{H} 1)$, diterima. Hasil penelitian ini menunjukkan bank sudah mampu membayar kembali seluruh kewajiban lancarnya.

2. Hasil pengujian analisis regresi diperoleh koefisien regresi EA sebesar 0,002 dan tingkat signifikan sebesar 0,695>0,05, maka variabel EA tidak berpengaruh signifikan terhadap NIM, berarti hipotesis kedua (H2), ditolak. Rasio EA mengukur persentase modal ekuitas yang terdapat dalam total aset. Bank dengan modal yang cukup akan memungkinkan bank untuk meningkatkan penyaluran kredit dan atau mengurangi kewajiban membayar hutang.

3. Hasil pengujian analisis regresi diperoleh koefisien regresi BOPO sebesar -0,001 dan tingkat signifikan sebesar 0,6301> 0,05, maka variabel BOPO tidak berpengaruh signifikan terhadap NIM, berarti hipotesis ketiga (H3), ditolak. Perusahaan adanya kenaikan biaya operasional yang mengakibatkan perusahaan tidak efisien.

4. Hasil pengujian analisis regresi diperoleh koefisien regresi ukuran bank sebesar -0,014 dan tingkat signifikan sebesar 0,132>0,05, maka variabel ukuran bank tidak berpengaruh signifikan terhadap NIM, berarti hipotesis keempat (H4), ditolak. Perusahaan adanya kenaikan total aset tetapi dalam hasil penelitian ini tidak menunjukkan bahwa ukuran bank mem-pengaruhi signifikan terhadap NIM.

5. Hasil pengujian analisis regresi diperoleh koefisien regresi NPL sebesar 0,026 dan tingkat signifikan sebesar $0,000<0,05$, maka variabel NPL berpengaruh signifikan terhadap NIM, berarti hipotesis kelima (H5), ditolak. Semakin tinggi tingkat Non Performing Loan, maka akan semakin menurun NIM.Dalam periode penelitian tahun 2012 -2016 pada perusahaan perbankan yang tercatat di BEI menunjukkan adanya kenaikan kredit bermasalah.

6. Hasil $\mathrm{F}$ hitung 15,409 dan tingkat probabilitas $0,000<0,05$, sehingga hipotesis keenam (H6) : Likuiditas, Modal Efisiensi, Ukuran Perusahaan dan Non Performing Loan mempunyai pengaruh signifikan terhadap Net Interest Margin (NIM) dapat diterima. NIM merupakan salah satu indikator profitabilitas bank (khususnya dalam usaha yang menghasilkan pendapatan bunga) sehingga NIM yang tinggi dapat menunjukkan profitabilitas yang tinggi (Iswi dan Toruan, 2010). 


\section{REFERENSI}

Adler, Haymans Manurung, 2014, Net Interest Margin : Bank Publik di Indonesia, Konsep dan Empiris. Pasar Modal dan Perbankan, Sampoerna School of Business

Anthony, Robert N dan Vijay Govindarajan. 2005. Management Control System Buku 2. Jakarta: Salemba Empat

Athanasoglou, P.P., Brissimis, S.N. \& Delis, M.D. 2008. Bank-specific, industry-specific and macroeconomic determinants of bank profitability. Journal of International Financial Markets, Institutions, \& Money, 18(2), 121-136.

Bank Indonesia, 2004 Surat Edaran Bank Indonesia Nomor 6/23/DPNP Perihal Sistem Penilaian Tingkat Kesehatan Bank. www.bi.go.id 31 Mei

Ben Naceur, S., dan Omran, M. 2011. The effects of bank regulations, competition, and financial reforms on bank's performance. Emerging Markets Review, 12(1), 1-20.

Brigham, Eugene F dan Houston, Joel F. 2011. Dasar-dasar Manjemen Keuangan Buku 1. (Alih Bahasa: Ali Akbar Yulianto). Jakarta : Salemba Empat.

Christiano, M; P. Tommy dan I. Saerang. 2014. Analisis Terhadap Rasio-Rasio Keuangan Untuk Mengukur Profitabilitas Pada Bank-Bank Swasta Yang Gopublic di Bursa Efek Indonesia. Jurnal EMBA. Vol.2. No.4. ISSN: 2303- 1174. 817-830.

Darwin, Ali, 2014, Penerapan Sustainability Reporting di Indonesia, Konvensi Nasional Akutansi V, Program Profesi Lanjutan, Yogyakarta

Djarwanto dan Pangestu Subagyo, 2009, Statistik Induktif, BPFE, Yogyakarta

Flamini, V., McDonald, C., Schumacher, L., 2009. The determinants of commercial bank profitability in sub-saharan Africa. IMF Working Paper 09/15. International Monetary Fund, Washington.

Ghozali, Imam 2013, Aplikasi Analisis Multivariate dengan Program SPSS, Undip, Semarang

Hasnawati, Sri. 2015. Dampak Set Peluang Investasi Terhadap Nilai Perusahaan Publik di Bursa Efek Jakarta. JAAI 9 (2). Hlm. 117-126.

Indah Lestari Dewi dan Nyoman Triaryati, 2017, Pengaruh Faktor Internal Dan Eksternal Bank Terhadap Net Interest Margin Di Indonesia, E-Jurnal Manajemen Unud, Vol. 6, No. 6, 2017: 3051-3079 ISSN : 2302-8912

Indonesian Capital Market Directory (ICMD), 2016

Iswi, Ariyanto, dan Toruan. 2010. Faktor Penentu Net Interest Margin Perbankan Indonesia. Finance and Banking Journal, 13(1) pp: 34-46.

Janrosl, Viola Syukrina E \& Yuliani, 2017, Analisis Kecukupan Modal, Risiko Kredit, Efisiensi Operasional, Pendapatan Dari Bunga Dan Likuiditas Terhadap Profitabilitas Perusahaan Perbankan Yang Terdaftar Di BEI, Jurnal Akuntansi, Vol. 6, No. 1, Oktober $2017: 51-64$

Jensen $\&$ Meckling, 1976, The Theory of The Firm: Manajerial Behavior, Agency Cost, and Ownership Structure, Journal of Financial and Ekonomics, 3:305-306

Kasmir. 2013. Manajemen Perbankan Edisi 1. Jakarta: PT. RajaGrafindo Persada.

Kosmidou, K., Zopounidis, C.. 2008. Measurement of Bank Performance in Greece. SouthEastern Europe Journal of Economics 1 79-95.

Maudos, J. dan Guevara JF.. 2011. Factors explaining the interest margin in the banking sectors of the European Union. Journal of Bankin Finance, 28: 2259-2281

Marozva, Godfrey, 2015, Liquidity And Bank Performance, International Business \& Economics Research Journal - May/June 2015 Volume 14, Number 3

Muljono. 2009. Akuntansi Manajemen : Konsep, Manfaat, Dan Rekayasa. STIE YKPN : Yogyakarta.

Nurliah, 2013, Analisis Pengaruh Karakteristik Bank Dan Inflasi Terhadap Net Interest Margin,Jurnal Manajemen Vol. 2, No. 3, 2013

Peraturan Bank Indonesia Nomor 14/ 15 /PBI/2012 Tentang Penilaian Kualitas Aset Bank Umum. 2012. Jakarta.

Sabir, Muh., Muhammad Ali, dan Abd. Hamid Habbe. 2012. "Pengaruh Rasio Kesehatan Bank Terhadap Kinerja Keuangan Bank Umum Syariah dan Bank Konvensional di Indonesia”. Jurnal Analisis. Vol.1 No.1, Juni 2012, 79-86 
Supomo, Bambang dan Nur Indriantoro, 2012, Metodologi Penelitian Bisnis Untuk Akuntansi dan Manajemen, Edisi Pertama BPFE, Yogyakarta.

Surat Edaran BI No. 15/15/PBI/2013 tentang Rasio Kredit Yang Diberikan Kepada Pihak Ketiga Dalam Rupiah Dan Valuta Asing

Taswan, Akuntansi Perbankan, UPP STIM YKPN, Yogyakarta 2009

Taswan. 2013. Manajemen Lembaga Keuangan Mikro BPR. Semarang: Badan Penerbit Fakultas Ekonomi Universitas Stikubank.

Taufik, Hidayat, Hamidah dan Umi Mardiyati, 2012, Analisis Pengaruh Karakteristik Bank Dan Inflasi Terhadap Net Interest Margin Studi Kasus Pada Bank Konvensional Yang Terdaftar di Bursa Efek Indonesia Tahun 2006-2010, Jurnal Riset Manajemen Sains Indonesia (JRMSI) Vol. 3, No. 1, 2012.

Tin, L.M., Ahmad, R., Shaharudin, S.S.. 2011. Determinants of Bank Profits and Net Interest Margins in East Asia and Latin America. Sumber: www.ssrn.com/abstract $=1912319$

Untari, Lisna, 2010, Pengaruh Karakteristik Perusahaan Terhadap Pengungkapan Laporan Tahunan, Simposium Nasional Akuntansi VII, Solo 